\title{
Peningkatan Tata Kelola BUM Desa Jaya Mandiri Bangkalan Melalui Pendampingan Intensif
}

\author{
Encik Muhammad Fauzan*, Indah Purbasari, Azizah \\ Prodi Ilmu Hukum Fakultas Hukum \\ Universitas Trunojoyo Madura \\ *E-mail : encik.fauzan@trunojoyo.ac.id \\ DOI: https://doi.org/10.21107/pangabdhi.v6i2.7605 \\ Naskah diterima 29 Juli 2020, Revisi 14 Agustus 2020, Terbit 29 Oktober 2020
}

\begin{abstract}
Abstrak
Badan Usaha Milik Desa (BUM Desa) Jaya Mandiri mengalami permasalahan dalam menjalankan tata kelola dan unit usahanya sehingga tidak dapat menghasilkan pendapatan yang maksimal. Namun pengelola BUM Desa "Jaya Mandiri” mempunyai semangat untuk terus memperbaiki tata kelolanya. Berdasarkan hal ini BUM Desa Jaya Mandiri melakukan pelatihan internal dari perguruan tinggi yang mampu mendampingi dalam memperbaiki tata kelola BUM Desa Mandiri. Metode yang digunakan adalah pelatihan dan pendampingan pengelolaan BUM Desa Jaya Mandiri agar menjadi lebih rapi dalam tata kelola administratif. Pendampingan dilakukan bukan hanya dengan memberikan pelatihan namun juga ikut serta dalam memperbaiki tata kelolanya secara intensif sehingga pengelola BUM Desa memahami tugas dan fungsinya dalam mengelola BUM Desa. Akan tetapi guna mempertahankan tata kelola yang baik perlu tiga hal yang harus dilakukan yaitu komitmen Pemerintah Desa untuk penyertaan modal dan pengawasan, komitmen, tanggung jawab dan kreatifitas dari pengelola serta masyarakat sebagai pengguna dari BUM Desa Jaya Mandiri.
\end{abstract}

Kata Kunci: Badan Usaha Milik Desa, tata kelola, pemerintah desa

\section{PENDAHULUAN}

Pengakuan keberadaan desa di Indonesia dapat dilihat dalam Pasal 18 ayat (2) UUD NRI Tahun 1945. Pasal ini memang tidak menyebut "desa" secara langsung, namun karakteristik desa ada didalamnya. Sehingga keberadaan Desa secara langsung berada di bawah Negara (Khafidi et.al, 2017). Sementara pengaturan desa diatur dalam Undang-Undang Nomor 6 Tahun 2014 tentang Desa (UU Desa) yang menunjukkan komitmen pemerintah terhadap pembangunan di desa. Keberadaan UU Desa memberikan implikasi yang luas bagi tata kehidupan masyarakat, utamanya pada kewenangan desa dan pemerintahan desa. Implikasi terhadap kewenangan desa menunjukkan bahwa otonomi desa tetep eksis, yang menjunjung tinggi kehidupan sosial budayanya (Kushandajani, 2016).

Keberadaan UU Desa juga telah memberikan perlindungan dan pengakuan terhadap masyarakat hukum adat dan hak-hak tradisionalnya melalui sebuah sistem penyelenggaraan Pemerintahan Desa. Oleh karena itu, penyelenggaraan pemerintahan desa memerlukan tata kelola pemerintahan yang baik yang dimulai dari perencanaan sampai pelaksanaan pembangunan dan evaluasi sehingga terwujudnya kesejahteraan masyarakat desa (Fauzan dan Hasanah, 2019).

Peningkatan kesejahteraan masyarakat desa melalui pembangunan perekonomian desa merupakan salah satu tugas dari pemerintahan desa. Desa sebagai kesatuan masyarakat hukum dalam tingkatan paling bawah menjadi ujung tombak dalam pembangunan. Perwujudan pembangunan desa perlu didukung oleh pengelolaan pembangunan yang partisipatif. Pada tatanan pemerintahan diperlukan perilaku pemerintahan yang jujur, terbuka, bertanggung jawab, dan demokrasi. (Isyanawulan et.al, 2016). Selain itu, landasan pemikiran dalam pemerintahan desa adalah keanekaragaman, partisipasi, otonomi asli, demokratisasi dan pemberdayaan masyarakat (Sugiman, 2018).

Perekonomian desa secara umumnya akan tergantung pada sumber daya alam atau sumber daya lainnya seperti pertanian, peternakan, perikanan, perkebunan dan lain sebagainya. Permasalahan yang sering muncul adalah bagaimana mengelola dan meningkatkan sumber daya alam yang ada di Desa dan sedikitnya 
pengaturan terkait sumber daya alam desa dalam UU Desa (Shohibuddin, 2016).

Pengelolaan sumber daya alam di desa salah satunya melalui pembentukan Badan Usaha Milik Desa (BUM Desa) yang merupakan wadah bagi pemerintah desa untuk mengembangkan usaha berdasarkan potensi yang ada di Desa tersebut. Pembentukan Badan Usaha Milik Desa (BUMDes) bertujuan untuk mendorong atau menampung seluruh kegiatan peningkatan pendapatan masyarakat, baik yang berkembang menurut adat istiadat dan budaya setempat, maupun kegiatan perekonomian yang diserahkan untuk di kelola oleh masyarakat melalui program atau proyek Pemerintah dan Pemerintah Daerah. Sebagai sebuah usaha desa, pembentukan BUMDes diharapkan mampu memaksimalkan potensi masyarakat desa dari aspek ekonomi, sumber daya alam, dan sumber daya manusianya (Chintary dan Lestari, 2016).

Keberadaan BUM Desa ini pun telah diatur dalam UU Nomor 6 Tahun 2014 tentang Desa. Pasal 87 UU Desa menyatakan bahwa Desa dapat mendirikan Badan Usaha Milik Desa yang dikelola dengan semangat kekeluargaan dan gotong royong. BUM Desa merupakan badan usaha yang seluruh atau sebagian besar modalnya adalah dimiliki oleh Desa melalui penyertaan secara langsung yang berasal dari dari kekayaan Desa yang dipisahkan guna mengelola aset, jasa pelayanan, dan usaha lainnya untuk sebesar-besarnya kesejahteraan masyarakat Desa.

Pengembangan BUM Desa merupakan salah satu bentuk penguatan kelembagaan ekonomi pada tingkat desa. Ini menjadi alat menggerakkan ekonomi desa berdasarkan pada potensi yang ada di desa. Oleh karena itu, kedudukan BUM Desa merupakan Lembaga professional yang harus dikelola secara mandiri tanpa campur tangan pemerintah desa (Fauzan dan Hasanah, 2016). BUM Desa juga merupakan bentuk pemberdayaan dari pemerintah berupa otonomi desa yaitu desa dapat mengelola sumber daya secara mandiri dan menopang kesejahteran warga desa, dan tentunya harapan tersebut dapat diiringi dengan meningkatnya Indeks Pembangunan Manusia (IPM) ( Fatimah, 2019).

Kepala Desa mempunyai peran strategis dalam mendorong perekonomian masyarakat desa melalui BUM Desa. Salah satu peran kepala desa yaitu sebagai fasilitator. Peran kepala desa sebagai fasilitator, bahwa kepala desa menjalankan perannya dalam hal memfasilitasi atau melengkapi kebutuhan, sarana dan prasarana yang mendukung proses pemerintahan dan pembangunan desa (Saleh dan Hariati, 2016). Selain fasilitator, kepala desa juga mempunyai peran sebagai mobilisator. Peran kepala desa sebagai mobilisator yaitu kepala desa menggerakan atau mengajak masyarakat untuk bersama-sama melakukan tindakan yang nyata untuk membangun desa (Aksan et.al, 2018).

BUM Desa "Jaya Mandiri" yang berlokasi di Desa Batangan Kecamatan Tanah Merah Kabupaten Bangkalan merupakan salah satu BUM Desa yang masih bertahan dari 273 desa yang telah mendirikan BUM Desa di Kabupaten Bangkalan. Pendirian BUM Desa ini pun dilandasi dengan semangat kekeluargaan dan kegotongroyongan para pemuda di Desa Batangan. Hal ini berdampak dari eksistensi BUM Desa ini masih dapat beroperasional meskipun terdapat permasalahan dalam kelola BUM Desa nya. Permasalahan yang ada pada BUM Desa Jaya Mandiri adalah tata kelola BUM Desa dan unit usaha yang masih terbatas seperti simpang pinjam dimana masyarakat yang meminjam dana pada BUM Desa tidak mematuhi ketentuan sehingga dana BUM Desa tidak bisa digunakan untuk pengembangan usaha lainnya.

Berdasarkan hal ini lah perlu pembenahan tata kelola BUM Desa dan pendampingan agar BUM Desa Jaya Mandiri mampu mandiri dalam pengelolaan dan masyarakat juga sadar pentingnya untuk berperan dalam pengembangan BUM Desa Jaya Mandiri. Masyarakat harus memahami bahwa peminjaman dana melalui BUM Desa Jaya Mandiri dapat meningkatkan pembangunan di Desa Batangan. Pengembalian peminjaman secara tepat waktu oleh peminjam dari masyarakat perlu untuk ditegakkan agar dana tersebut dapat digunakan untuk pengembangan BUM Desa Jaya Mandiri.

\section{METODE}

Berdasarkan permasalahan yang telah diuraikan diatas, maka perlu penanganan permasalahan tersebut dengan menggunakan metode pelatihan dan pendampingan bagi pengelola BUM Desa Jaya Mandiri. Pelatihan merupakan salah satu bentuk memberikan pengetahuan dan ketrampilan kepada peserta untuk memahami dan mempraktekan dari materi yang diberikan.

Pelatihan dan pendampingan dilakukan pada bulan Juni sampai dengan bulan Juli 2019. 
Adapun pelaksanaan ini dilakukan dengan beberapa tahapan. Tahapan pertama dilakukan pada minggu pertama dan kedua bulan Juni 2019 mengidenfikasi permasalahan dan kebutuhan pada BUM Desa Jaya Mandiri.

Tahapan kedua dilaksanakan pada minggu ketiga dan keempat Juni 2019 dengan agenda mempersiapkan materi dan bahan untuk pendampingan dan pelatihan. Adapun bahanbahan yang dipersiapkan untuk materi pendampingan dan pelatihan yaitu peraturan perundang-undangan, buku-buku terkait pemerintahan desa dan BUM Desa. Selain itu alat yang digunakan berupa laptop, LCD Proyektor, layar untuk LCD Proyektor, pengeras suara, kertas, buku tulis, buku kas, dan buku administrasi. Khusus untuk kegiatan rumah jamur, bahan diperlukan yaitu bambu, kayu, anyaman bambu, plastik dan paku. Sedangkan peralatan gergaji, palu dan lain-lain.

Tahapan ketiga merupakan tahap pelaksanaan pendampingan dan pemberian pelatihan yang dilakukan pada minggu pertama sampai minggu ketiga bulan Juli 2020. Pendampingan dilakukan dalam membenahi persyaratan pembentukan BUM Desa, pembenahan manajemen organisasi, keuangan dan pemasaran. Pelatihan dilakukan dalam bentuk pelatihan tata Kelola BUM Desa dan pengembangan Rumah Jamur. Tahapan keempat yaitu melakukan evaluasi dari rangkaian kegiatan tahapan pertama sampai tahap ketiga. Tahapan keempat ini dilakukan pada minggu keempat bulan Juli 2019. Tahapan kelima merupakan tahapan terakhir yaitu penyusunan laporan. Penyusunan laporan kegiatan pengabdikan kepada masyarakat ini juga dilakukan pada minggu keempat Juli 2019.

Metode pelatihan ini biasanya lebih efektif dibandingkan hanya memberikan materi saja tanpa dipraktekan oleh peserta. Selain itu menggunakan metode pelatihan, juga digunakan metode pendampingan bagi peserta dalam kurun waktu tertentu. Pendampingan adalah mendampingi peserta pada saat melaksanakan tugas dalam mengelola BUM Desa. Pendamping dalam hal ini memberikan arahan dan masukan ketika dalam menjalankan pengelolaan sehingga peserta atau pengelola bukan hanya mempraktekkan dalam dibantu secara langsung dalam pengelolaan BUM Desa.

Penggunaan metode pelatihan dan pendampingan intensif sangat tepat digunakan dalam membantu memperbaiki tata kelola BUM Desa Jaya Mandiri. Karena permasalahan yang dihadapi oleh BUM Desa Jaya Mandiri bukan hanya tata kelola nya saja akan tetapi sumber daya manusianya juga perlu ditingkatkan agar dapat mengelola BUM Desa Jaya Mandiri semakin baik dan maju.

\section{HASIL DAN PEMBAHASAN}

Badan Usaha Milik Desa (BUM Desa) Jaya Mandiri terletak pada Desa Batangan Kecamatan Tanah Merah Kabupaten Bangkalan. BUM Desa Jaya Mandiri ini didirikan berdasarkan Peraturan Desa Batangan Nomor 1 Tahun 2017. Adapun tujuan dari pembentukan BUM Desa Jaya Mandiri ini adalah meningkatkan perekonomian Desa, mengoptimalkan asset Desa dan kesejahteraan Desa, meningkatkan usaha masyarakat dalam pengelolaan potensi ekonomi desa, mengembangkan rencana kerja sama usaha desa dengan pihak ketiga, menciptakan peluang dan jaringan pasar yang mendukungkebutuhan layanan umum masyarakat desa, membuka lapangan kerja bagi masyarakat desa dan meningkatkan pendapatan masyarakat Desa dan Pendapatan Asli Desa.

Tujuan pembentukan BUM Desa Jaya Mandiri ini ditegaskan pula dalam pasal 2 Peraturan Desa Batangan Nomor 1 Tahun 2017 tentang Badan Usaha Milik Desa Jaya Mandiri. BUM Desa Jaya Mandiri ini dapat membentuk berbagai unit usaha salah satunya unit usaha bisnis yang berbadan hukum privat dengan kepemilikian saham yaitu $60 \%$ dimiliki oleh BUM Desa Jaya Mandiri dan 40\% dapat dimiliki oleh masyarakat. Namun sampai saat ini unit usaha yang berbentuk badan hukum ini belum terbentuk. Adapun unit usaha yang ada adalah peternakan, simpan pinjam dan pelayanan pembayaran listrik atau pembayaran lainnya.

Unit usaha peternakan pada BUM Desa Jaya Mandiri terdiri dari peternakan kambing Etawa dan budidaya ayam petelur. Kedua usaha ini pun tidak berjalan dengan baik khususnya usaha kambing Etawa. Sedangkan usaha budidaya ayam petelur hanya cukup untuk menutupi keuangan operasional saja. Sementara pada unit usaha pelayanan pembayaran, BUM Desa Jaya Mandiri bekerjasama dengan salah satu perbankan. Unit usaha ini juga sebenarnya cukup baik mendapat tanggapan dari masyarakat karena masyarakat dapat melakukan pembayaran listrik, BPJS Kesehatan dan pembelian pulsa melalui unit ini. Akan tetapi yang menjadi permasalahan dalam kerjasama ini adalah bagi hasil antara pihak perbankan dan BUM Desa Jaya Mandiri 
karena menurut pihak perbankan akan ada bagi hasil jika jumlah transaksi lebih dari 200 transaksi dalam satu bulan. Hal ini menyebabkan BUM Desa Jaya Mandiri masih sedikit dalam memperoleh bagi hasil.

Unit usaha yang dilakukan oleh BUM Desa Jaya Mandiri ini adalah simpan pinjam. Unit usaha ini paling banyak diminati oleh masyarakat khususnya dalam peminjaman dana usaha. Namun antara simpanan dan peminjaman lebih banyak peminjaman daripada simpanan. Selain itu, masyarakat yang melakukan peminjaman melalui BUM Desa Jaya Mandiri ini juga tidak melakukan setoran peminjaman secara tepat waktu. Unit usaha peminjaman ini pun dilakukan oleh BUM Desa Jaya Mandiri tanpa anggunan asal digunakan untuk mengembangkan usaha masyarakat. Sistem pengembaliannya pun dilakukan secara diangsur setiap bulan dengan kompensasi marjin $1.15 \%$ dari jumlah pinjaman.

Pengelolaan BUM Desa Jaya Mandiri selain diatur dalam Peraturan Desa Batangan Nomor 1 Tahun 2017 tentang BUM Desa Jaya Mandiri, juga diatur tata kelolanya melalui Anggaran Dasar dan Anggaran Rumah Tangga BUM Desa Jaya Mandiri (AD/ART BUM Desa Jaya Mandiri). Namun selama kurang lebih 2 tahun berdiri sejak tahun 2017, AD/ART ini belum selesai sehingga menyebabkan mekanisme pengelolaan di BUM Desa Jaya Mandiri kurang maksimal.

\section{Pelatihan dan Pendampingan Tata Kelola BUM Desa}

Perbaikan tata kelola pada BUM Desa Jaya Mandiri dilakukan dengan pelatihan-pelatihan mengenai tata kelola BUM Desa. Pelatihan ini bertujuan untuk meningkatkan kemampuan pengelola dan kader-kader BUM Desa yang hampir semuanya masih mudah dan mempunyai semangat dalam melakukan sesuatu yang lebih baik. Adapun pelatihan-pelatihan yang diberikan pada pengelola dan kader BUM Desa Jaya Mandiri meliputi materi dokumen-dokumen pendirian BUM Desa, organisasi BUM Desa, pembukuan keuangan BUM Desa, keadministrasian BUM Desa serta pengembanan usaha kreatif.

Pada materi tentang dokumen pendirian BUM Desa maka terdapat 4 (empat) dokumen penting yang harus ada yaitu peraturan desa mengenai pendirian BUM Desa, Akta Notaris, Surat Keputusan Kepala Desa mengenai pengelola BUM Desa dan Anggaran Dasar/Anggaran
Rumah Tangga BUM Desa. Berkaitan dengan semua dokumen ini, hanya dokumen Anggaran Dasar/Anggaran Rumah Tangga BUM Desa Jaya Mandiri yang harus segera diselesaikan. Oleh karena itu, dalam pelatihan ini juga difokuskan pentingnya AD/ART tersebut serta menjelaskan bagaimana penyusunan AD/ART yang baik. $\mathrm{AD} / \mathrm{ART}$ ini sangat penting sebagai pedoman pengelola dalam melakukan pengelolaan BUM Desa seperti pelaksanaan rapat-rapat apa saja yang seharusnya dilakukan oleh pengelola BUM Desa.

Pada materi berikutnya dalam pelatihan tata kelola BUM Desa ini adalah menjelaskan dan mengevaluasi struktur organisasi BUM Desa Jaya Mandiri. Berdasarkan SK Kepala Desa Batangan Nomor 188/08/kpts/433.313.20/2019 tentang Anggota Pelaksana Operasional dan Pengawas BUM Desa Jaya Mandiri Desa Batangan maka susunan dan keanggotaan pelaksana operasional. Struktur organisasi pelaksana operasional pada BUM Desa Jaya Mandiri diatas sangatlah sederhana. Maka pada pelatihan tersebut diberikan materi bahwa susunan ideal dari sebuah BUM Desa adalah terdiri dari Dewan Komisaris/Penasehat, Direktur, Sekretaris, Bendahara dan beberapa Kepala Unit Usaha serta terdapat satu Badan Pengawas. Secara umumnya Dewan Komisaris atau Penasehat dijabat oleh Kepala Desa atau tokoh masyarakat. Dewan Komisaris mempunyai kewajiban memberikan nasehat kepada pelaksana operasional dalam melaksanakan pengelolaan BUM Desa, memberikan saran dan pendapat mengenai masalah yang dianggap penting bagi pengelolaan BUM Desa dan mengendalikan pelaksanaan kegiatan pengelolaan BUM Desa berdasarkan program kerja yang telah disepakati. Selain itu, Penasehat juga berwenang untuk meminta penjelasan dari pelaksana operasional mengenai persoalan yang menyangkut pengelolaan usaha dalam BUM Desa dan melindungi usaha Desa terhadap halhal yang dapat mengganggu kinerja BUM Desa.

Pola hubungan pelaksana operasional juga diberikan pada pelatihan ini agar mengetahui dan melaksanakan dengan baik bagaimana pola hubungan kerja dalam satu tim pengelola BUM Desa atau sebagai pelaksana operasional. Adapun hal-hal yang dapat membangun kerja yang baik dalam pengelolaan BUM Desa adalah:

1. Membangun tim kerja yang baik dengan menyusun daftar pekerjaan dan 
pembagian kerja yang jelas sesuai dengan tugas pokok dan fungsinya.

2. Menyusun kebutuhan anggaran yang sesuai dengan perencanaan dan program kegiatan.

3. Mencari modal usaha dalam mengembangkan usaha dalam BUM Desa baik penyertaan modal dari pemerintah desa maupun penanaman saham dari masyarakat.

4. Mengurus aspek legalitas atau melengkapi dokumen-dokumen legalitas dalam BUM Desa

5. Merancang produk atau unit usaha sesuai dengan kebutuhan masa kini atau masyarakat setempat.

6. Melengkapi sarana dan prasarana dalam pengelolaan BUM Desa.

7. Merancang strategi promosi unit usaha dalam BUM Desa.

8. Merancang program kegiatan untuk peningkatan kapasitas SDM pengelola BUM Desa dan peningkatan usaha kreatif.

Penanganan permasalahan yang dihadapi oleh BUM Desa Jaya Mandiri selain dengan materi-materi diatas juga diberikan terkait dengan pembukuan keuangan dan administrasi. Pembukuan keuangan sangat penting untuk dapat menghasilkan laporan keuangan sebagai bahan dalam penyusunan program dan pengembangan usaha BUM Desa. Laporan keuangan yang sederhana tapi dapat dipertanggungjawaban adalah hal yang harus dilakukan dalam pengelolaan keuangan pada BUM Desa Jaya Mandiri. Pelaporan keuangan dilakukan pada setiap bulan dan tutup buku keuangan pada setiap tahun. Oleh karena itu pada setiap tahun juga harus diadakan rapat yang harus dihadiri oleh Dewan Komisaris, Badan Pengawas dan Pelaksana Operasional.

Tata laksana admnistrasi merupakan bagian dari tata kelola BUM Desa yang baik. Tata kelola ini meliputi dari pembuatan rutin laporan keuangan, pengarsipan dan pencatatan admnistrasi. Pembuatan rutin laporan keuangan dilakukan oleh Bendahara, sementara pengarsipan dan pencatatan administrasi dilakukan oleh sekretaris. Ketiga kegiatan ini dapat pula dibantu oleh staf pada masing-masing jabatannya. Selain pemberian materi-materi tersebut, juga dibimbing dalam menjalan materi yang telah diberikan. Pembimbingan atau pendampingan ini lakukan secara intensif oleh tim abdimas dari Universitas Trunojoyo Madura yang melakukan pengabdian di Desa Batangan Kecamatan Tanah Merah Kabupaten Bangkalan. Pendampingan intensif dilakukan pertama, melakukan pendampingan dalam tata kelola BUM Desa secara langsung dengan pengelola. Kedua melakukan monitoring terhadap pelaksanaan tata kelola yang dilakukan satu minggu sekali, dan ketiga melakukan evaluasi diakhir pendampingan. Setelah tiga tahap ini dilakukan, tim abdimas juga masih melakukan pendampingan sebagai bentuk keberlanjutan yang dilakukan satu bulan setelah pelaksanaan pendampingan secara intensif. Pendampingan secara intensif dilakukan selama satu minggu dan monitoring kemajuan dilakukan satu minggu sekali selama tiga kali. Pelaksanaan pelatihan dan pendampingan secara intensif dapat memberikan konstribusi minimal memperbaiki tata kelola BUM Desa Jaya Mandiri yang semakin tertata dengan baik.

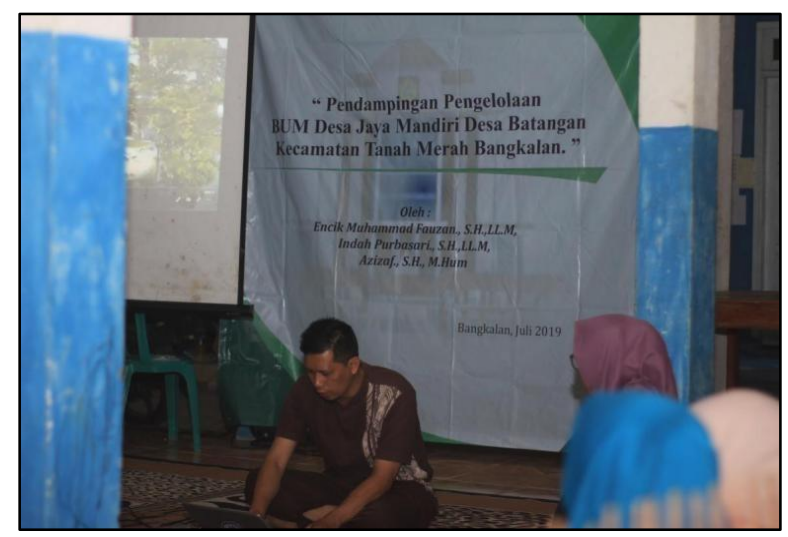

Gambar 1. Pemberian Materi Pelatihan

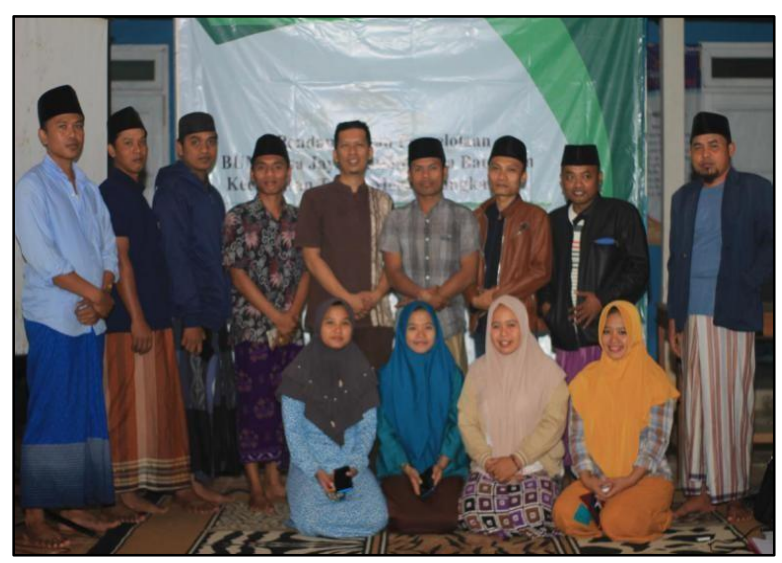

Gambar 2. Peserta Pelatihan

\section{Pengembangan Usaha Rumah Jamur}

Pengembangan usaha pada BUM Desa Jaya Mandiri sangatlah penting sehingga tidak hanya mengandalkan pada tiga unit usaha yang telah 
ada. Guna untuk meningkatkan pengembangan usaha pada BUM Desa Jaya Mandiri ini, maka diadakan pelatihan terkait pengembangan unit usaha sebagai bentuk pengembangan usaha kreatif. Adapun pelatihan yang diberikan dalam pengembangan usaha ini adalah pelatihan rumah jamur. Rumah jamur (kumbung) merupakan tempat khusus untuk menyimpan media tanaman dalam proses budidaya jamur. Tujuan dari adanya rumah jamur ini, supaya pertumbuhan jamur dapat tumbuh dengan baik dan menghasilkan jamur yang berkualitas, baik dari segi berat ataupun bentuknya. Jenis jamur yang digunakan dalam proses budidaya ini, yaitu jamur tiram. Jamur tiram putih (pleurotus ostreatus) saat ini cukup pupuler dan banyak digemari oleh masyarakat karena rasanya yang lezat dan juga penuh kandungan nutrisi, tinggi protein, dan rendah lemak. Manfaat yang didapatkan dari jamur tiram putih yaitu mampu meningkatkan metabolisme dan menurunkan kolesterol, anti bakterial, serta anti tumor sehingga jamur tiram juga banyak dimanfaatkan untuk mengobati berbagai macam penyakit mulai dari diabetes, lever, dan lainnya.

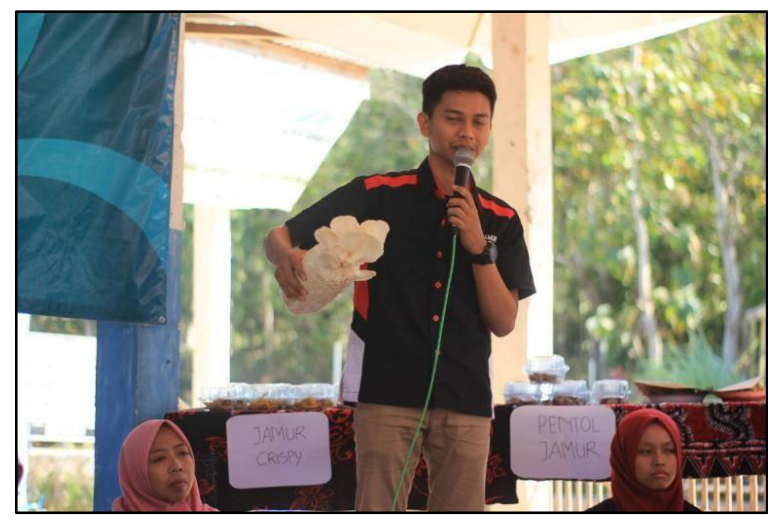

Gambar 3. Pelatihan Budidaya Jamur

Rumah jamur umumnya terbuat dari bahan dasar bambu, dimana kumbung terbaik adalah kumbung yang dapat menjaga kelembapan optimal yang dibutuhkan untuk perkembangan jamur tiram. Atap kumbung terdiri dari tiga lapisan, dimana lapisan paling luar menggunakan genting, selanjutnya lapisan kedua terdapat terpal/plastik, dan lapisan terakhir atau lapisan paling dalam terdapat jerami. Tujuannya yaitu untuk menjaga kelembapan rumah jamur itu sendiri. Di dalam rumah jamur terdapat rak yang digunakan sebagai tempat baglog (media tanam). Pada pelaksanaan program rumah jamur ini dibagi menjadi 3 tahap yaitu persiapan, pelaksanaan dan monitoring. Pada tahap persiapan penanggung jawab program beserta anggota menyiapkan bahan-bahan yang akan digunakan dalam pengolahan jamur.

Tahap selanjutnya adalah pelaksanaan, program ini dilaksanakan pada hari Minggu tanggal 7 Juli 2019. Dalam pelaksanaannya ini dibantu oleh mahasiswa yang juga melakukan Kuliah Kerja Nyata dari kelompok 90 Univesitas Truonojoyo Madura. Para mahasiswa ini membantu masyarakat dalam mempersiapkan dan membuat jamur tiram dan sekaligus mensosialisasikan mengenai aturan kepada para pengunjung mengenai rumah jamur.

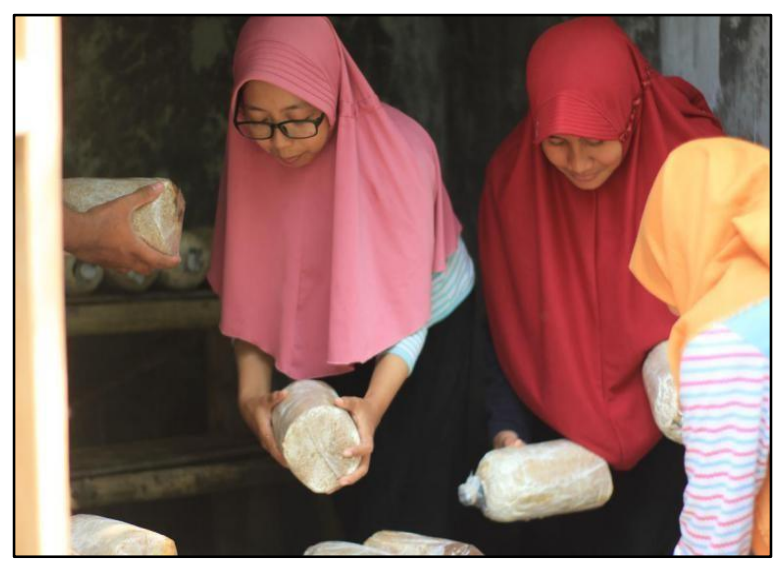

Gambar 4. Hasil Rumah Jamur

Tahap yang terakhir adalah monitoring, dimana monitoring ini dilaksanakan setiap hari untuk mengontrol apakah pertumbuhan jamur subur dan bernilai guna. Manfaat dari pelatihan ini adalah memberikan informasi tentang budidaya jamur tiram kepada masyarakat desa Batangan serta memberikan peluang usaha baru bagi masyarakat Desa Batangan.

Hasil yang didapatkan dalam pelatihan ini adalah masyarakat Desa Batangan dapat mengetahui tata cara pengelolaan budidaya jamur tiram, masyarakat Desa Batangan dapat mengkonsumsi jamur setiap hari tanpa harus menunggu satu tahun sekali untuk menunggu jamur di hutan dan dampak yang timbul dari kegiatan ini adalah masyarakat Desa Batangan dapat lebih mendalami tentang jamur tiram untuk dijadikan produk unggulan di Desa Batangan serta dapat dikelola melalui BUM Desa Jaya Mandiri.

\section{KESIMPULAN}

Pengembanan BUM Desa Jaya Mandiri dapat dilakukan melalui dua kegiatan yaitu Pelatihan dan Pendampingan Tata Kelola BUM Desa dan Pelatihan usaha kreatif melalui pengembangan usaha Rumah Jamur. Kegiatan pelatihan dan 
pendampingan ini dilakukan selama dua bulan untuk menghasilkan BUM Desa Jaya Mandiri yang lebik baik dan maju. Adanya komitmen dan kesadaran dari Pemerintah Desa Batangan dan pelaksana operasional BUM Desa Jaya Mandiri dapat mempercepat perkembangan BUM Desa Jaya Mandiri. Selain pelatihan dan pendampingan tata kelola BUM Desa, juga terdapat pelatihan pengembangan usaha melalui pelatihan rumah jamur yang sangat mudah untuk dikembangkan di Desa Batangan.

\section{UCAPAN TERIMA KASIH}

Penulis mengucapkan terima kasih kepada LPPM Universitas Trunojoyo Madura yang telah memberikan dana hibah Pengabdian Kepada Masyarakat melalui Kompetisi Hibah Abdimas Semester Genap Tahun 2019.

\section{DAFTAR PUSTAKA}

Aksan, Limba, H. R. S., \& Tanzil. 2018. Peran Kepala Desa Dalam Meningkatkan Pembangunan Desa (Studi di Desa Baliara Selatan, Kabupaten Bombana). Neo Societal. Vol 3 (1). 244-253 pp. https://doi.org/10.1017/CBO9781107415324. 004

Chintary, V., \& Lestari, A. 2016. Peran Pemerintah Desa Dalam Mengelola Badan Usaha Milik Desa (Bumdes). Jurnal Ilmu Sosial Dan Ilmu Politik Universitas Tribhuwana Tunggadewi. Vol 5 (2). 59-63 pp.

Fauzan, E. M., \& Hasanah, U. 2019. Pembentukan Peraturan Desa di Desa Telang dan Gili Timur - Bangkalan. Jurnal Ilmiah Pangabdhi. Vol 5 (2). 97-102 pp. https://doi.org/10.21107/pangabdhi.v5i2.6111

Isyanawulan, O. G \& Budiawan, M. A. 2016. Peranan Kepala Desa Dalam Meningkatkan Kesejahteraan Masyarakat (Studi Kasus Budidaya Ikan Lele Didesa Talang Ipuh
Kecamatan Suak Tapeh Kabupaten Banyuasin). Jurnal Sosiologi USK (Media Pemikiran \& Aplikasi). Vol 10 (2). 89-103 pp. https://doi.org/10.24815/jsu

Khafidi, F., Prihatin, E. S \& Hardjanto. 2017. Penyelenggaraan Pemerintahan Desa di Desa Bedono Kecamatan Sayung Kabupaten Demak Menurut Undang-Undang Nomor 6 Tahun 2014 tentang Desa. Diponegori Law Journal. Vol 6, 1-20 pp.

Kushandajani. 2016. Implikasi UU No. 6 Tahun 2014 Tentang Desa Terhadap Penyelenggaraan Pemerintahan Desa. Jurnal Ilmiah Ilmu Pemerintahan. Vol 2 (1). 53-64 pp. https://doi.org/10.14710/jiip.v2i1.1635

Fatimah, P. 2019. Mengembangkan Kualitas Usaha Milik Desa (Q-BUMDes) untuk Melestarikan Ketahanan Ekonomi Masyarakat dan Kesejahteraan Adaptif: Perancangan Sistem Kewirausahaan Desa dengan Menggunakan Model Tetrapreneur. Jurnal Studi Pemuda. Vol 7 (2). 122-130 pp. https://doi.org/10.22146/studipemudaugm.39 551

Saleh, S., \& Hariati. 2016. Peran Kepala Desa Sebagai Administrator Pembangunan Di Desa Moncongloe Kecamatan Moncongloe Kabupaten Maros. Jurnal Office. Vol 2 (2), 143-148.

https://doi.org/10.1017/CBO9781107415324. 004

Shohibuddin, M. 2016. Peluang dan Tantangan Undang-undang Desa dalam Upaya Demokratisasi Tata Kelola Sumber Daya Alam Desa: Perspektif Agraria Kritis. MASYARAKAT: Jurnal Sosiologi. Vol 21 (1). 1-33 pp. https://doi.org/10.7454/mjs.v21i1.5021

Sugiman, S. 2018. Pemerintahan Desa. Binamulia Hukum. Vol 7 (1). 82-95 pp. https://doi.org/10.37893/jbh.v7i1.16 
Fauzan, E.M., Purbasari, I \& Azizah Peningkatan Tata Kelola BUM Desa 79 